\title{
ABOVE AND BELOW
}

\section{The distribution of mermaid, siren and sirène place names across Canada and the creation of related tourist attractions}

[Received January 8th 2021; accepted May 1st 2021 - 10.21463/shima.114]

\section{Philip Hayward}

\author{
University of Technology, Sydney <prhshima@gmail.com>
}

\begin{abstract}
European colonists applied terms from their language cultures to various geographical features in territories they explored, occupied and/or settled in. In Canada this resulted in a number of locations being named after mermaids, the French equivalent, sirènes, or the related term sirens. This article provides a survey of these Canadian place names, including discussions of those few whose name origins are known. It also profiles two sites where the manufacture and installation of mermaid statues has resulted in mermaid-themed location naming and related tourism promotion. Discussion of the two examples leads to consideration of the promotional value of mermaid names, associations and visual branding.
\end{abstract}

KEYWORDS: mermaid, sirène, place names, Canada, destination branding

\section{Introduction}

Toponymy, the study of the nature and origination of place names, is a well-established area of research that has acquired particular inflections in recent decades as it has shifted it from an essentially introverted discipline to one with more substantial engagement with cultural and/or political aspects of place-naming. A small but significant body of what might be referred to as critical toponymy has addressed various impacts of colonisation on non-western territories (e.g. Castañeda, 2010; Bradley, 2015), mainly focusing on the erasure of prior indigenous names. A related strand has addressed what Smyth (2017: 3536) refers to as the role of toponyms "in commemorating, validating and (re)producing colonial histories." Smyth's work is of particular significance for this article by exploring how "the enactment, production and narrativization of history through everyday geography... serves to reproduce colonial histories of commemoration." In particular, he highlights the role of place names "in presenting taken for-granted colonial historical geographies that at once blatantly signal settler privilege... while also fading into the background of everyday life" (ibid: 36). While Smyth focuses on examples in urban Toronto, this article takes another approach, surveying and analysing the distribution of linked European terms - mermaid/siren/sirène - across Canada. These particular names have been chosen as a topic drawing on recent critical-analytical work on the internationalisation of the European derived folkloric figure of the mermaid/siren (e.g. Hayward [ed], 2018; Shima, 2018) and the manner in which she both embodies deep symbolic characteristics and represents processes of cultural imperialism. While research has been undertaken on spectacular representations of mermaids, in sculpture, for instance (Jepsen, 2017), or in contemporary audio-visual media (Hayward, 2017), research 


\section{Hayward: Above and Below}

and analysis of the lower-key practice of mermaid-themed place-naming has only recently been attempted (e.g. Young 2021a, 2021b; Fleury and Hayward, 2021). As a contribution to the latter area of research, this article highlights the relatively arbitrary nature of many mermaid/siren/sirène place names in Canada, which have been scattered across various mostly isolated - coastal, lacustrine and mountainous areas without obvious points of connection with landscape and/or prior indigenous place names or cultural traditions. Indeed, it is notable there is no apparent incidence ${ }^{1}$ in Canada of a mermaid/siren/sirène place name being affixed to a location with prior associations with Indigenous water spirits in a similar manner to the Mermaid Pools in the Bargo River in eastern Australia (Bodkin and Bodkin-Andrews, 2001), or the Mermaid Pools at Matapouri, North Island, New Zealand (home to two Maori taniwha spirits ${ }^{2}$ ). Similarly, there are no officially recognised Canadian place names that commemorate Indigenous figures such as the Inuit Sedna or Inuk Taliilajuq (often represented with human upper parts and fish-tailed lower bodies).

Unlike Australia, a fellow Commonwealth dominion which has close to 40 locations named after mermaids (Fleury and Hayward, 2021), provincial and national government place name databases (and additional Google Map and archival searches) reveal that Canada currently has relatively few named locations $(16)^{3}$ but also has 5 locations named after the sirène (the French equivalent of mermaid ${ }^{4}$ ) in the predominantly francophone province of Quebec and 2 locations named after sirens, in Ontario, ${ }^{5,6}$ The survey of these place names offered in this article reveals small provincial clusters and several provinces without mermaid place names. Given the lack of information about the origins of the majority of mermaid-named places in official databases and my inability to find reliable information from other sources, I am only able to provide discussion of the origins of a small number of place names and, indeed, query the official explanation of one of these. The second section provides case studies of two locations - Mermaid Cove (CMo4), in British Columbia, and Mermaid Rock (CM16), Ontario - whose place naming is well documented, deriving from the creation and installation of mermaid sculptures in marine and lacustrine locations. In the discussion of the representation of these sights, I follow Lavrenova (2019) and my previous co-authored study of Australian mermaid named locations elsewhere in this issue (Fleury and Hayward, 2021) by addressing "the 'sign

\footnotetext{
${ }^{1}$ I use the qualification "apparent" here since there is no indication of the reason for the majority of Canadian mermaid/siren place names (and the possibility for such an association in some cases cannot therefore be discounted).

${ }^{2}$ See TeAra.govt.z (n.d.) for background on the taniwha in Maori culture.

${ }^{3}$ I use the qualifier "currently" as there may have been locations that once had such appellations that have fallen into disuse. Mermaid Hill (Newfoundland) - discussed briefly below - is one such locale but there may have been others.

${ }^{4}$ While the term mermaid predominantly refers to fish-tailed aquatic females, sirène has a broader meaning in French, also referring to fully human-formed figures associated with water or mysterious, alluring women more generally.

${ }^{5}$ It is unclear whether the two siren place names in Ontario (CSo6, CSo7) have francophone origins (and may have been originally orally referred to or spelled as sirène) or whether they use the similar term 'siren' common in English language usage.

${ }^{6}$ There are also two locations in British Columbia named Sirenia Glacier and Sirenia Mountain. The word sirenia is not a common variant of siren (meaning a mythological, aquatic female) but is, instead, a Latin term for the zoological genus that includes dugongs and manatees. For this reason, the two locations are not included and described in this survey. However, it should be acknowledged that their location, in close proximity to Mermaid Peak ( $\left.\mathrm{CM}_{13}\right)$, to the east, and Manatee and Dugong peaks, to the south, suggests a continuum of associations between the mythological and zoological designations.
} 


\section{Hayward: Above and Below}

systems' that are one component of intangible cultural heritage contributing to the character and perception of lived landscapes" (ibid: xx).

Spatial coordinates for each of the locations discussed in the article are detailed in appendices 1 and 2. The place coding numbers for each location refer to the data in the appendices.

\section{The distribution of mermaid and sirène place names across Canada}

With the exception of the cluster of Mermaid named locations on PEI (CMo2, CMo5, $\mathrm{CM} 13$ ), the two Nunavut locales (CMo6 and $\mathrm{CMo}$ ) Mermaid Cove in British Columbia (CMo4) and Mermaid Rock in Ontario ( $\mathrm{CM}_{15}$ ), all the place names identified below occur in remote, unpopulated areas and designate landmark features rather than communities. Broken down by province, these comprise:

- British Columbia (BC) (5): Mermaid Mountain (CM12) and Mermaid Peak (CM13) in the Rockies; Mermaid Cove (CMo4), in Saltery Bay; Mermaid Bay (CMoz), on Dent Island in the Discovery Islands; and Mermaid Point (CM14), on Nelson Island.

- Newfoundland: Somewhat surprisingly, given its historic mermaid folklore (see, most notably, Whitbourne, 1620), Newfoundland currently has no officially designated mermaid place names. ${ }^{7}$ It should be noted that Maxwell (1878: 61) identifies a Mermaid Hill located on Davis Island, off the Burin peninsula but this name appears to have fallen into disuse.

- Nunavut (2): Mermaid Fiord (CMo6) and Mermaid Island (CMo7) ${ }^{8}$, on Baffin Island.

- Ontario (7): Two Mermaid Lakes (CM1o, CM11); in Kenora and in the Algonquin Park; two Mermaid Islands (CMo8, CMog), on the eastern side of Lake Huron and in the St. Lawrence River, north-east of Kingston; and Mermaid Rock (CM16), in Rainy Lake. It also has Siren Lake (CSo7) and the inflowing Siren Creek (CSo6) in Algoma.

- Prince Edward Island (PEI) (3): A small community named Mermaid (CMoz), located east of Charlottetown, with an area on the adjacent coast named Mermaid Cove (CMo5) and a small lake to the west named Mermaid Pond $^{9}\left(\mathrm{CM}_{15}\right) .^{10}$

- Quebec (6): Île Mermaid in Lac Chibougamau (CMol) and also 5 locations named after la sirène: Île Sirène (CSo1), south-east of Lac Hélène; Lac Sirène (CSo5), in the Côte-deBeaupré, north of Quebec City; and three locations named Lac de la Sirène, in Eeyou Istchee Baie-James (CSo2), in le Fjord-du-Saguenay (CSo3) and in la Vallée-de-l'Or (CSo4)."

\footnotetext{
${ }^{7}$ Internet searches also identified Mermaid Cove, on the east coast of the Avalon Isthmus, and Mermaid Rock in Twillingate. Despite their designations, these are the names of businesses rather than place locations.

${ }^{8}$ Mermaid Island, in Mermaid Fiord, is not identified in Canadian placename databases but is referred to in other reports, such as Peacock (2007).

${ }^{9}$ Also occasionally referred to as Mermaid Lake.

${ }^{10}$ Despite the existence of an establishment named the Siren's Beach Motel in north-east PEI, there is no location named Siren's Beach on PEI.

${ }^{11}$ Natural Resources Canada's Geographical (nd) data refers to this as Lac Sirenia but Lac de la Sirène is the more usual designation.
}

Shima Volume 15 Number 22021 


\section{Hayward: Above and Below}

NB Alberta, Manitoba, New Brunswick, Nova Scotia, Northwest Territories, Saskatchewan and The Yukon have no recorded mermaid, siren or sirène place names.

With the exception of Lac de la Sirène (CSoz), the cluster of Mermaid named locations on PEI (CMo2, CMo5, CM15), the two Nunavut locales (CMo6 and CMo7), Mermaid Cove (CMo4) and Mermaid Rock ( $\left.\mathrm{CM}_{1} 6\right)$, there is no indication in provincial place name databases or other sources that the names of these other locations are anything other than arbitrary designations. This does not, of course, rule out any association with settler or indigenous folklore or with other cultural-historical aspects in their naming but research has not uncovered any information concerning these. Given that the majority of mermaid/siren/sirène named places in Canada occur in remote, uninhabited regions it is unsurprising that a) the names are relatively arbitrary; and b) the names have not resulted in themed visual association or destination branding (since there are no governmental or commercial agencies actively engaged in promoting these specific areas).

In toponymic terms, Lac de la Sirène (CSoz) is notable for having an official account of a folkloric origin of its name (unlike the identically named $\mathrm{CSO}_{3}$ and $\mathrm{CS}_{4}$ ) but this is somewhat problematic. The Quebec Commission de Toponymie identifies the name of CSo2 as derived from Captain Henry Hudson's encounter with a mermaid in the Gulf of Saint Lawrence in $1608 .{ }^{12}$ Attempting to associate the lake with the sighting, the Commission de Toponymie claims that Hudson "probably reached James Bay which is upstream" [i.e. upstream from Lac de la Sirène] (n.d.: online). ${ }^{13}$ Whether this speculation concerning Hudson's route is accurate or not, it is unclear how the lake became associated with the mermaid that Hudson and his crew sighted elsewhere and the explanation for the place name is thereby highly tendentious. An alternative explanation, offered by White (1910: 5), is more credible, stating that the island was named after a British gunboat operating in the Great Lakes in 1812-184.

In contrast, accounts of the origins of clusters of mermaid place names in PEI and Nunavut are more straightforward. In a similar manner to that of Australia, where the voyages of Captain Phillip Parker King onboard the HMC Mermaid in 1818-1822 left a trail of mermaid-themed place names around the coast of the continent (Fleury and Hayward, 2021), a small cluster of mermaid place names in Queens County, in central PEI, appear to have derived from the presence of the British vessel HMS Mermaid in the area in 176os. Rayburn (1973: 84) provides the main source for such perceptions, outlining a complex process by which a cove adjacent to the Hillsborough River near the current community of Mermaid (CMoz) was initially named Dean Cove in 1765, in honour of Captain Joseph Dean who visited PEI on board the HMS Mermaid in 1764-65, with the name transitioning to Mermaid Cove $\left(\mathrm{CMo}_{3}\right)$ at an undisclosed date in the mid-late 2oth Century. Rayburn

\footnotetext{
${ }^{12}$ Hudson detailed the encounter in the following terms: This morning, one of our companie looking over boord saw a mermaid, and calling up some of the companie to see her, one more came up, and by that time shee was come close to the ship's side, looking earnestly on the men: a little after, a sea came and overturned her: from the navill upward, her backe and breasts were like a woman's, as they say that saw her; her body as big as one of us; her skin very white; and long haire hanging downe behinde, of colour blacke: in her going downe they saw her tayle, which was like the tayle of a porposse, and speckled like a macrell. (1860: online)

${ }^{13}$ There are also folkloric accounts of mermaids in the Bas-du-Fleuve are of the Fleuve Saint-Laurent (Gulf of Saint Lawrence) - see Dupont (34-35), for instance - but these do not appear to have led to any related place names in the area.
}

Shima Volume 15 Number 22021

- 224 - 


\section{Hayward: Above and Below}

also identifies that the designation Mermaid Farm, which was applied to a nearby lot in 1864, was also named after the HMS Mermaid following "several round-trips during the spring-to-fall period between Halifax and Quebec" during which the ship "sometimes stopped at Port Joy ${ }^{14}$ for a few days" (Lockerby, 2014: online). Rayburn also identifies that a small pool to the east of Mermaid Farm, which had previously been known as MacEacherns Pond, became known as Mermaid Pond (CM15) around 1965 (Rayburn, 1973: 77). The present-day unincorporated community of Mermaid appears to date back to the early 1800 , with its Presbyterian cemetery dating back to 1830 . The name Mermaid was officially adopted in the provincial register of PEI place names in 1925 before being changed to Mermaid Farm in 1939 and then back to Mermaid in 1960 (Government of PEI, n.d.: online). The area also gives its name to the PEI parliamentary constituency of MorellMermaid, established in 1996. Reflecting the lack of tourist attractions, facilities or themed products in the area there has been little attempt to develop the mermaid theme in destination or product branding in the manner that Fleury and Hayward identify with regard to parts of Australia's Gold Coast (2012: 92-94) and, indeed, the principal signage of the name in the area occurs on signs on Fort Augustus Road (Figure 1) that runs through the area (Figure 1) and on the gates of the uniquely named local cemetery (without complementary figurative representation) (Figure 2). ${ }^{15}$

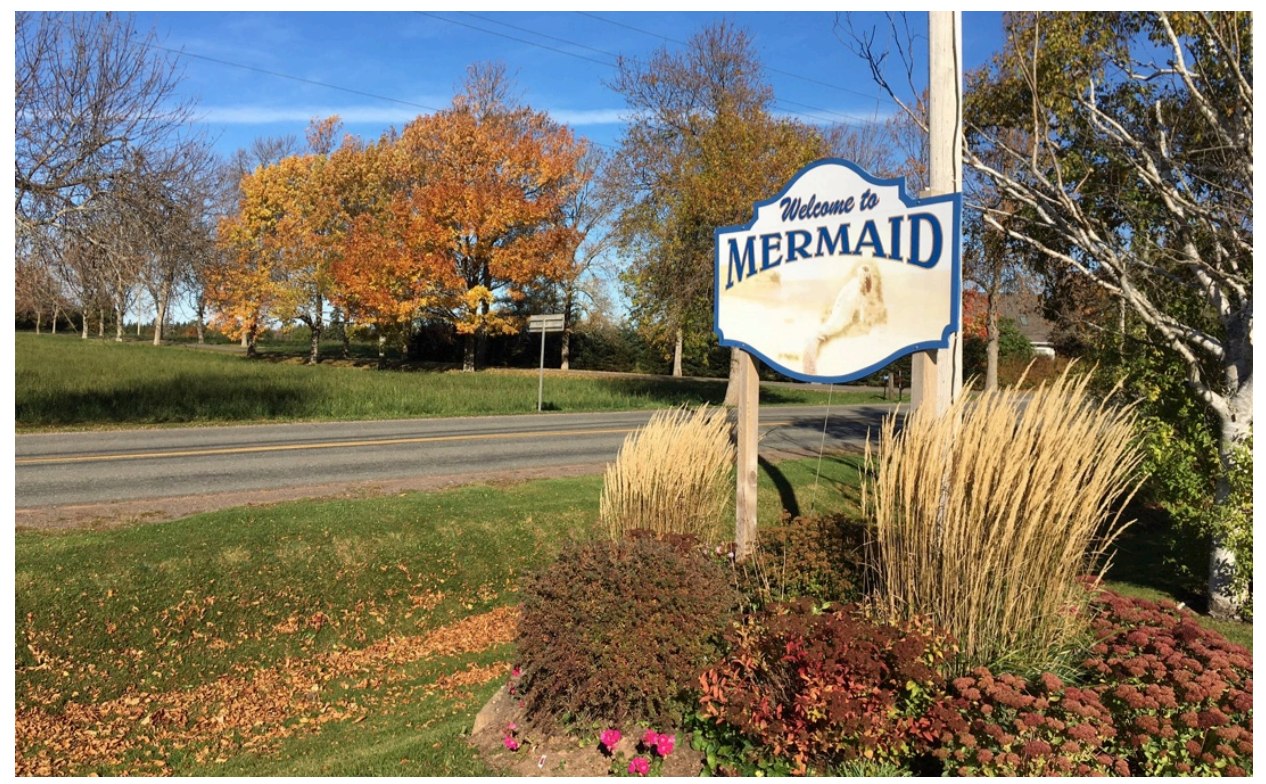

Figure 1 - Mermaid street sign, Mermaid PEI (CMo2) (Nathan Coleman, 2017)

\footnotetext{
${ }^{14}$ Port Joy, now the Skmaqn-Port-la-Joye-Fort Amherst historical site, was the initial capital of PEI.

${ }^{15}$ Despite its title, the annual Mermaid Tears Seaglass festival, held in Souris, in eastern PEI, is not connected to area.
} 


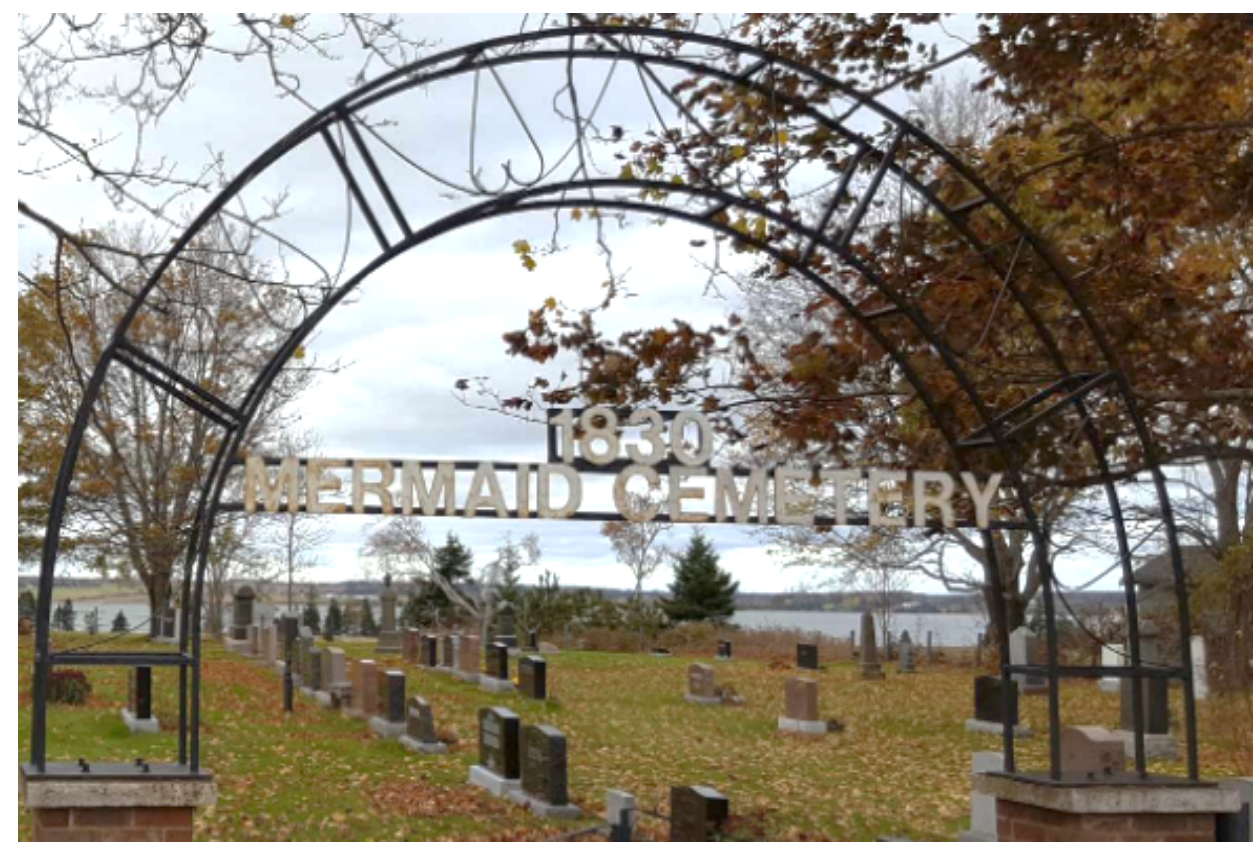

Figure 1 - The main entrance to Mermaid Cemetery, Mermaid, PEI (CMoz) (Billion Graves, n.d.)

On Baffin Island, the name Mermaid Fiord (CMo6) was proposed for a location now known by the Inuit as Kangiqtujjuaq (literally "big long bay") by American explorer and climber Dr B.V.D. Cochran in $1968 .{ }^{16}$ Unlike a number of other proposals for place names that Cochran made (Nunatsiaq News, 2010), his suggestion to name the fiord after the Mermayde, one of John Davis' ships on his 1586 expedition to the Canadian Arctic, was accepted by the Canadian Secretariat for Geographical Names and used in subsequent official maps of the area. The name Mermaid Island, given to a small island in the Fiord, is not officially recognised but has been cited in reports such as Peacock (2007).

\section{Fabricated themed locations}

While many mermaid (or siren) place names outside of the United Kingdom have been applied to locations without prior associations with the folkloric figure, some have been able to activate them for particular purposes. As Fleury and Hayward (2021) detail, the area around Mermaid Beach in the south-eastern corner of the state of Queensland, is a case in point. The beach was originally named after the survey ship HMC Mermaid, which visited the area in 1823. The beach was a quiet location for much of the following 120 years until it became developed as a tourist centre located at the southern end of (what became known as) Australia's Gold Coast. In the context of beach-oriented leisure (often characterised in terms of ${ }_{4} \mathrm{~S}$ tourism - i.e. Sun, Sea, Sand, Sex), mermaids were an appealing visual symbol and were 'organically' rooted in the locale by virtue of prior place-naming (as opposed to

\footnotetext{
${ }^{16}$ Thanks to Lynn Peplinski for providing me with this information (personal correspondence, January 2021).
} 


\section{Hayward: Above and Below}

invented designations for other beaches such as, most, obviously, Surfers Paradise). The nomenclative associations of the area were significantly boosted by mermaid themed signage and statuary from the mid-196os on, much of which actively drew on media-loric associations derived from films such as Disney's The Little Mermaid (Clements and Musker, 1989) and the TV series $\mathrm{H}_{2} \mathrm{O}$ : Just Add Water (2006-2010) and Mako Mermaids (2013-2018), both of which were shot around the Gold Coast and represented it on screen.

In addition to opportunistic capitalisations on pre-constituted mermaid place names, a related practice has involved the design and installation of mermaid statues in places with no prior association with the 3 that subsequently result in the areas being associated with mermaids and, in some instances (such as those discussed below), of place naming that reflects this association. The two examples discussed below differ by representing an idiosyncratic early 2oth Century family project that was subsequently inscribed in local place naming and visual representation (Mermaid Rock) and a far more calculated late 2oth Century project, designed to attract tourists through themed attractions (Mermaid Cove).

\section{a. Mermaid Rock (Ontario) (CM16)}

The installation of a mermaid statue on a small rock on the Canadian side of Rainy Lake, which straddles the Canada-US border, immediately to the north-west of Fort Frances, and the subsequent naming of the rock after the statue, represents an early 2oth Century example of the internationalisation of mermaid imagery that followed the publication of Hans Christian Andersen's short story 'The Little Mermaid' (1837). The statue's direct inspiration was Edvard Eriksen's famous statue of a mermaid (or, rather, of a human female with finned lower legs), which was installed on a rock adjacent to Langelinie promenade in Copenhagen in 1913. Though closely associated with the protagonist of Hans Christian Andersen's short story, the model and inspiration for the statue was Danish ballerina Ellen Price, who performed as lead in a ballet adaptation of the story in Copenhagen in 1909. Danish brewer, art collector and philanthropist Carl Jacobsen was so impressed by Price's performance that he commissioned Eriksen to produce a bronze statue inspired by her (an aspect that explains the figure's finned feet, as Price danced in a costume with similar lower leg adornments). Sometime in the late 1920 or early 1930 , two Canadians, Henry and Mer Lynse, visited Copenhagen and were fascinated by the statue (Watson, 2004). After returning to their home on Rest Island, on the Canadian (northern) side of Rainy Lake (440 kilometres north-east of Minneapolis), they were keen to erect a similar statue. The opportunity to accomplish this arose in 1935, when a young architectural student and relation, Gordon Schlichting, was spending the summer with them. Schlichting interpreted their wish without close adherence to the design of Eriksen's statue, choosing instead to create the figure of a more buxom adult female with full fishtail (Figure 2). After transporting a concrete block reinforced with metal to a small rock off the north-east point of the island, he chiseled the figure in an example of what is now be referred to as 'guerilla art', where creative works are produced and installed in public places without permission from relevant authorities. While the Lynses' reactions to having such a different mermaid figure installed off the shore of their island has not been documented, the structure has remained in place for over 75 years and has become a popular local landmark and photo-stop opportunity for recreational sailors, resulting in the (previously un-named) rock becoming colloquially known as Mermaid Rock and being formally recognised as such by the Canadian Names Board in 1970. ${ }^{17}$

\footnotetext{
${ }^{17}$ This account is synthesised from Unattributed (2002) and Watson (2004).
} 


\section{Hayward: Above and Below}

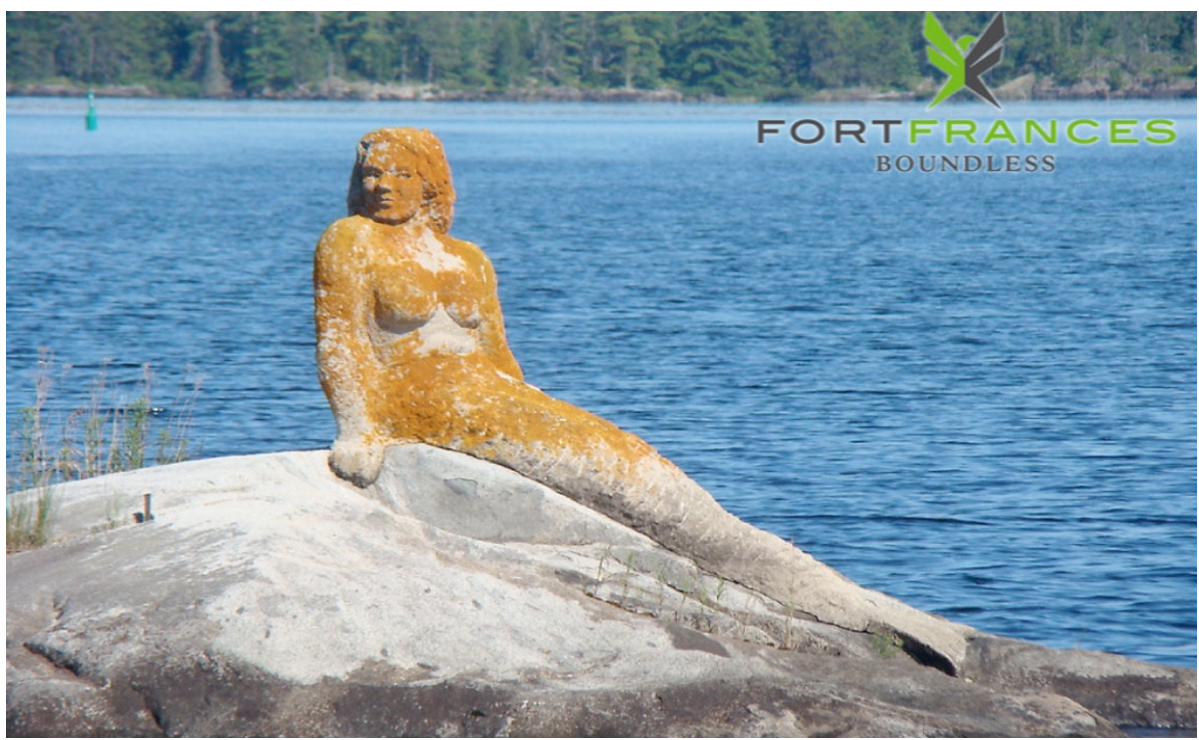

Figure 3 - Promotional Image of Mermaid Rock (CM16) (Fort Frances, n.d)

There appears to be no account of initial local reactions to the erection of the statue but in recent decades it has become recognised as something of a local heritage asset and was the subject of an art show entitled 'Mermaid Imagery' organised by local group Rainy Lake Impressions in August 2002. The exhibition featured a number of works inspired by the statue and the recitation of a poem written for the event by local Ruth writer Caldwell. One interpretation of Schlichting's design, a thin, metal statue, has been installed with an information panel about the original statue on La Verendrye Parkway outside of Fort Frances (Figure 4), further boosting the mermaid's profile.

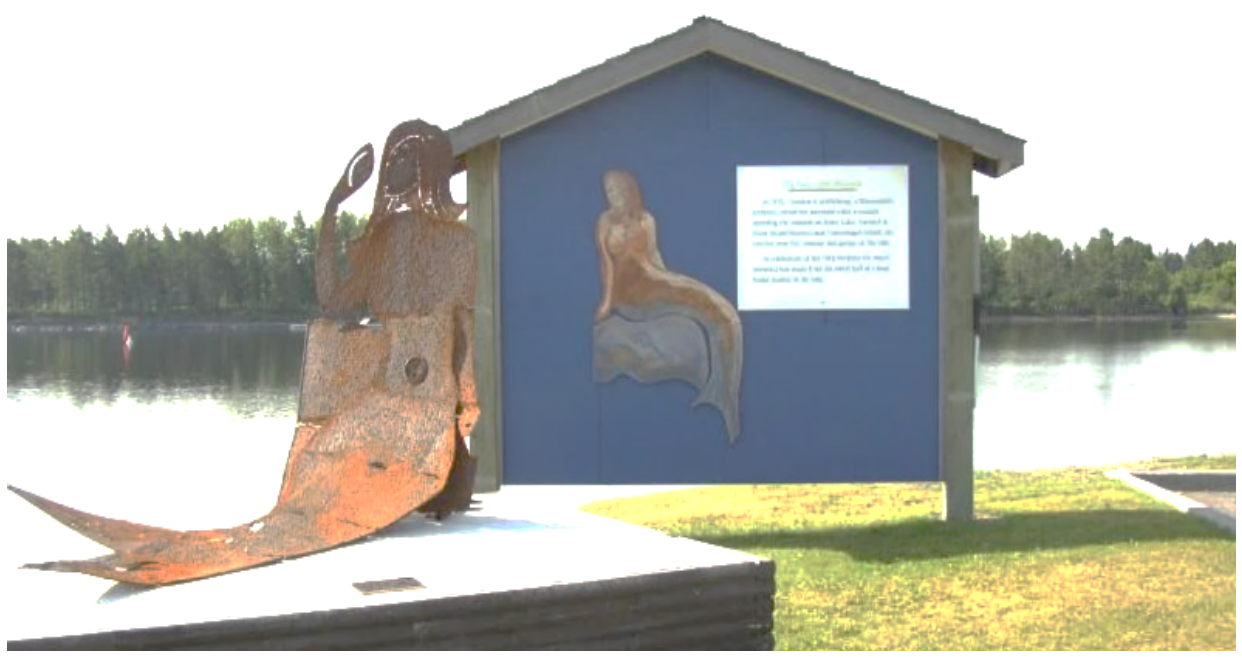

Figure 4 - Metal mermaid statue and information panel (Fort Frances, n.d) 
The most recent interpretation of the local mermaid in popular media occurred in the form of Lake of the Woods Brewing Company (based in Kenora) which launched their Rainy Lake Blonde Ale in 2018, featuring a stylised rendition of the mermaid on the bottle label (Figure 5). A publicity note accompanying the beer's initial release referred to the statue's history and identified that the mermaid, "statuesque, secretive and alluring, is said to watch over the comings and goings of the Lake" and playfully identifying that the beer itself was "soon to be the stuff of local lore". While the initial erection of the statue appears to have been innocent of any intention to destination brand the locale, such branding has clearly occurred in recent years and has been advantageous to the marketing of the Fort Frances and Rainy Lake area. The case of Mermaid Cove, BC (CMo4), is markedly different in that its mermaid sculpture was specifically designed to attract tourists and its designation was almost immediately used in local tourism promotion.

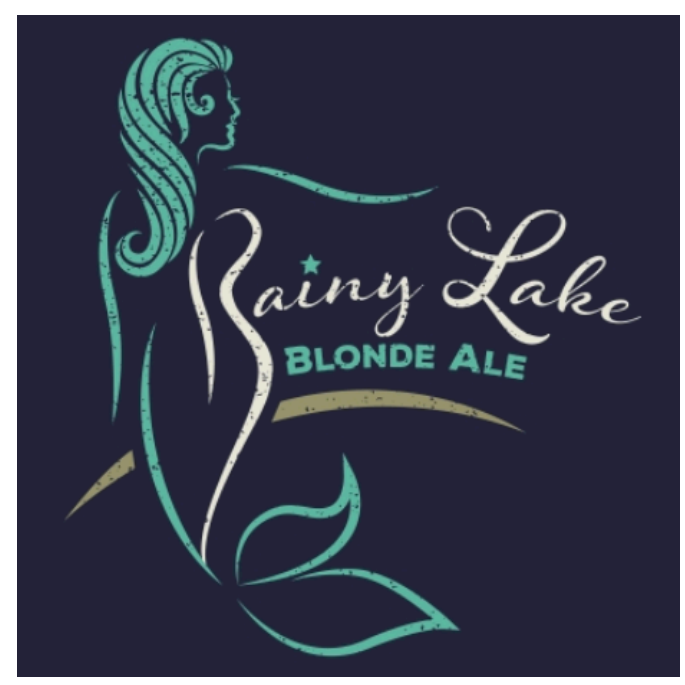

Figure 5- Rainy Lake Blonde Ale beer label (2018).

\section{b. Mermaid Cove (British Columbia) (CMo4)}

Saltery Bay, in the north-east corner of the Strait of Georgia, takes its name from a fish saltery that operated in the area in the early 190os (BC Parks, nd). The area is relatively remote, requiring visitors from Vancouver (the nearest and, indeed, only city in its vicinity) to take two car ferries when driving north-east to it on a $140 \mathrm{~km}$ route that generally takes 4 hours to transit. The name Mermaid Cove was applied to an area of the bay adjacent to Powell River shortly after the installation of a 2.75 metre high underwater sculpture entitled 'The Emerald Princess' in 1989 (Figure 6). The trend of creating underwater sculptures specifically to attract divers commenced in 1954 when Italian sculptor Guido Galletti created a 2.8 metre bronze statue entitled 'Il Cristo degli Abissi' which was sunk off the coast of Portofino, Italy in 1954. The mould for the statue was subsequently used to create a second version, entitled 'Christ of the Abyss', sunk off Key Largo Park in Florida in 1965, that became a major attraction for recreational divers (Sterner, 2004: 44). The success of these early examples led to a number similar works being created, including 'The Emerald Princess,' a hollow, metallic statue made by diver, artist and environmentalist Simon Morris in 1986-89. Morris's work represented the second attempt to install a mermaid statue in Saltery Bay. The idea for the statue was 


\section{Hayward: Above and Below}

originated by local resident Jodi Willoughby in the early 1980 os and was brought to realisation by her husband Jim Willoughby (Unattributed, 1989). The first version, a stone one, representing a mermaid reclining on kelp fronds, broke-up during removal from its construction studio and further work on it was abandoned. Shortly after the second statute was safely installed, BC Parks applied for the registration of the name Mermaid Bay, which was officially gazetted in January 1990. Soon after, BC Parks installed new signage around Saltery Bay Campground (as it was them known) in a rebranding exercise designed to capitalise on media coverage of the statue's successful immersion and of mermaid associations more generally. Popular cultural commemorations of the site followed, including a song entitled 'The Tin and Copper Mermaid of the West,' written and recorded by Canadian songwriter Eugene Krauss, ${ }^{18}$ and various visual representations of the underwater sculpture that circulated on the Internet in the 1990 and 2000 s as social media platforms developed. A dedicated Facebook page (entitled 'The Emerald Princess: Saltery Bay's Mermaid ${ }^{19}$ ) was launched in 2014 in conjunction with 25th Anniversary festivities that saw a mass dive to the site and an accompanying onshore event that was widely covered in local and BC provincial media. A local press report published in 2014 summarised the impact of the statue's installation in the following appreciative terms:

The mermaid has also brought fame and fortune to Powell River... While the dive industry has suffered setbacks over the past few years, the Mermaid Cove dive remains a must-see for aquanauts touring $B C$, and it's often the destination for weekend trips from Vancouver. (Percy, 2014: 25)

While the author does not mention it, there is likely a value to having a coastal area and associated dive site named after a mermaid - in addition to the value of the sculpture itself - in that it its connotations are more romantic than those of the fish saltery that gives the broader area its name.

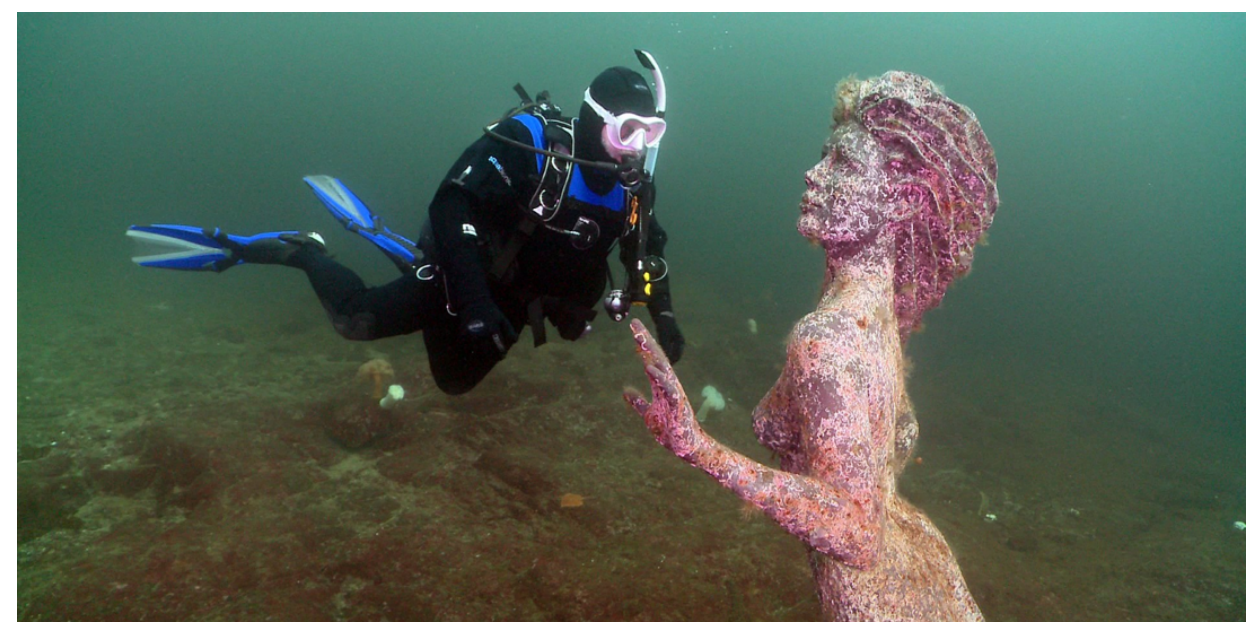

Figure 6 - Diver and upper part of Emerald Princess sculpture, Mermaid Bay (profile image from ‘The Emerald Princess: Saltery Bay's Mermaid' Facebook page (Neil McDaniel, 2016)

\footnotetext{
${ }^{18}$ Featured on his album Cueball (release date unknown).

${ }^{19}$ The Facebook page - https://www.facebook.com/MermaidPowellRiver/ - has postings documenting the initial construction of the sculpture and various postings and shots of divers interacting with her.
} 


\section{Hayward: Above and Below}

\section{Conclusion}

The association of particular Canadian places with mermaids, sirens or sirènes through place-naming detailed in this article represents the imposition of European cultural figures upon a North American landscape that supported rich and complex First Nations' cultural heritage and place-naming traditions that are now substantially overlaid by European ones. The seemingly arbitrary nature of many mermaid/siren/sirène place name designations in contemporary Canada thereby supports Smyth's characterisation that such practices "blatantly signal settler privilege... while also fading into the background of everyday life" (2017: 36). This article has attempted to bring a cluster of place names out of "the background" in order to illustrate their arbitrariness and to contrast this to place names more closely associated with settler history, such as the PEI and Nunavut clusters, or those that reflect the more recent constructions of mermaid figures in natural settings, i.e. Mermaid Rock and Mermaid Cove. The article has also illustrated how the ubiquity of the mermaid/siren/sirène in popular culture has extended to nomenclature and of how her representation continues to attract attention in a manner that promotes the locations in question. While there is little (if any) folkloric underpinning of the names of the Canadian localities in question, we can identify what might be termed a weakly folkloresque effect (Foster and Tolbert, 2016) to be in play, generated by place names and, in some instances, ancillary representations that serve and exemplify the commemoration, validation and reproduction of colonial histories within spatial designations.

\section{Acknowledgements:}

Thanks to Richard Green and Simon Young for their assistance in compiling the list of Canadian place names detailed in Section I. Thanks also to Laurie Brinklow for additional information on Mermaid [PEI], Philip Hiscock for consultations on Newfoundland, Lynn Peplinski for information on Inuit place names in Nunavut and Sean Percy for additional information on Mermaid Cove.

\section{BIBLIOGRAPHY}

Bodkin, F and Bodkin-Andrews, G (2001) D'harawal Dreaming stories: Migadan - the legend of the Bargo River: https://dharawalstories.files.wordpress.com/2015/12/migadan.pdf accessed 12th December 2020

Bradley, K (2020) 'What's in a name? Place names, history, and colonialism', Active History 2nd February: http://activehistory.ca/2015/o2/whats-in-a-name-place-names-history-andcolonialism/ - accessed 12th December 2020

British Columbia Parks (nd) 'Saltery Bay Provincial Park': https://bcparks.ca/explore/parkpgs/saltery/ accessed 14th December 2020

Castañeda, Q (2002) 'Post/colonial topynomy: Writing Forward 'in Reverse,' Journal of Latin American Cultural Studies v11 n2: 119-134

Dupont, J-C. (1985) Légendes du Saint-Laurent II, Saint-Foy: self-published

Fleury, C and Hayward, P (2020) 'Shipped Ashore: The origins and deployment of Mermaid place names in Australia and related visual representations', Shima v15 n2: xx-xx 


\section{Hayward: Above and Below}

Hayward, P (2017) Making a splash: mermaids (and mermen) in $20^{\text {th }}$ and early $21^{\text {st }}$ century audiovisual media, Eastleigh: John Libbey \& Co./Indiana University Press

Hayward, P (ed) (2018) Scaled for success: the internationalisation of the mermaid, Eastleigh: John Libbey \& Co./Indiana University Press

Hudson, H (1860) The Navigator: the original documents in which his career is recorded, collected, partly translated and annotated, London: Asher, online at: https://archive.org/stream/henryhudsonnavig27ashe/henryhudsonnavig27ashe_djvu.txt accessed 12th December 2020

Lake of the Woods Brewing Company (2018) 'Rainy Lake Blonde Ale' (promotional material):

https://www.facebook.com/rainylakesquare/photos/a.660362414160355/816353811894547/ accessed 12th December 2020

Lavrenova, O (2019) Spaces and meanings: semantics of the cultural landscape, Berlin: Springer

Lockerby, E (2014) 'Off to a rocky start', The Guardian (Charlottetown) 18th October: https://www.pressreader.com/canada/the-

guardiancharlottetown/20141018/282291023487994 - accessed 12th December 2020

Maxwell, W.F (1878) The Newfoundland Pilot, London: Hydrographic Office, Admiralty

Mermaid Rock (nd) 'Mermaid Rock': https://mermaidrock.ca/ - accessed 12th December 2020

Nunatsiaq News (2010) 'James Mutch on the map', Nunatsiaq News 9th April: https://nunatsiaq.com/stories/article/98789_taissumani_april_9/ - accessed 12th December 2020

Peacock, E (2007) Davis Strait population survey interim report, Igloolik: Wildlife Research Section, Department of Environment

Percy, S (2014) 'Diva of the deep: The original story of Powell River's most famous 25-yearold', Powell River Living March: 24-25.

Jepsen, P (2017) Mermaids of Earth, Dunedin: self-published

Rayburn, A (1973) Geographical names of Prince Edward Island, Ottawa: Surveys and Mapping Branch, Department of Energy, Mines and Resources

Shima (2018) v12 n2 - Theme issue on 'Mermaids, mercultures and the aquapelagic imaginary', https://shimajournal.org/issues.php\#previous - accessed 12th December 2020

Smyth, B (2017) 'Cartographies of colonial commemoration: Critical toponymy and historical geographies', Journal of the Canadian Association for Curriculum Studies v15 n2: $35-47$ 


\section{Hayward: Above and Below}

Sterner, B (2004) 'Underwater sculpture viewers take swimmingly to trend', Espace Sculpture n68: 43-44

TeAra.gov.za (nd) 'Taniwha': https://teara.govt.nz/en/taniwha/print - accessed 13th December 2020

Unattributed (1989) Mermaid Emerald Princess - Powell River, BC March 1989, online at: https://www.youtube.com/watch?v=YYdq2oQjGSI\&feature=youtu.be\&fbclid=IwAR24ycEjV 9kymEWwLxLE9ZY2bCOiAAJBTUHpkqXXSN6Wb5aDMPdR_J6OIeE - accessed 12th December 2020

Unattributed (2002) 'Mysteries of mermaid revealed at art show', Fort Frances Times 14th August: https://www.fftimes.com/news/news/mysteries-mermaid-revealed-art-show accessed 1st January 2021

Watson, A (2004) 'A Rainy Lake reflection', Rainy Lake Conservancy Newsletter 6v nı: 1

White, J (2010) Place-names in the Thousand Islands of the St. Lawrence River, Ottawa: Government Printing Bureau

Whitbourne, R (1620) 'Preface to A Discourse and Discovery of New-Found-Land', London, archived online at: https://collections.mun.ca/digital/collection/cns/id/23942 - accessed 19th December 2020

Young, S (2021a) 'Mermaids, mere-maids and no maids: Mermaid place names and folklore on Britain', Shima v15 n2: 176-201

Young, S (2021b) 'Mermaid toponyms in the West Indies', Shima v15 n2: 202-220

\section{Appendix 1 - Mermaid place names in Canada (and ID numbers used in article)}

\section{ID Location name}

CMo1 Île Mermaid

$\mathrm{CMo} 2$ Mermaid

CMo3 Mermaid Bay

CMo4 Mermaid Cove

CMo5 Mermaid Cove

CMo6 Mermaid Fiord

CMo7 Mermaid Island

CMo8 Mermaid Island

CMog Mermaid Island

CMıo Mermaid Lake

CMı Mermaid Lake

CM12 Mermaid Mountain

$\mathrm{CM}_{13}$ Mermaid Peak

CM14 Mermaid Point

$\mathrm{CM}_{15}$ Mermaid Pond

CM16 Mermaid Rock

\section{Province}

Quebec

PEI

British Columbia

British Columbia

PEI

Nunavut

Nunavut

Ontario

Ontario

Ontario

Ontario

British Columbia

British Columbia

British Columbia

PEI

Ontario

\section{Coordinates}

$49^{\circ} 51^{\prime} 51^{\prime \prime} \mathrm{N}-74^{\circ} 13^{\prime} 47^{\prime \prime} \mathrm{W}$

$46^{\circ} 15^{\prime} 43^{\prime \prime} \mathrm{N}-63^{\circ} 2^{\prime} 11^{\prime \prime} \mathrm{W}$

$50^{\circ} 24^{\prime} 11^{\prime \prime} \mathrm{N}-125^{\circ} 11^{\prime} 18^{\prime \prime} \mathrm{W}$

$49^{\circ} 46^{\prime} 42^{\prime \prime} \mathrm{N}-124^{\circ} 11^{\prime} 35^{\prime \prime} \mathrm{W}$

$46^{\circ} 15^{\prime} 59^{\prime \prime} \mathrm{N}-63^{\circ} 3^{\prime} 4^{\prime \prime} \mathrm{W}$

$66^{\circ} 14^{\prime} \mathrm{o}^{\prime \prime} \mathrm{N}-62^{\circ} 44^{\prime} \mathrm{o}^{\prime \prime} \mathrm{W}$

$66^{\circ} 14^{\prime} \mathrm{o}^{\prime \prime} \mathrm{N}-62^{\circ} 44^{\prime} \mathrm{o}^{\prime \prime} \mathrm{W}$

$44^{\circ} 17^{\prime} 41^{\prime \prime} \mathrm{N}-76^{\circ} 11^{\prime} 20^{\prime \prime} \mathrm{W}$

$44^{\circ} 52^{\prime} 36^{\prime \prime} \mathrm{N}-79^{\circ} 49^{\prime} 14^{\prime \prime} \mathrm{W}$

$50^{\circ} 2^{\prime} 28^{\prime \prime} \mathrm{N}-94^{\circ} 5^{\prime} 39^{\prime \prime} \mathrm{W}$

$45^{\circ} 33^{\prime} 21^{\prime \prime} \mathrm{N}-78^{\circ} 46^{\prime} 34^{\prime \prime} \mathrm{W}$

$51^{\circ} 46^{\prime} 55^{\prime \prime} \mathrm{N}-118^{\circ} 8^{\prime} 26^{\prime \prime} \mathrm{W}$

$50^{\circ} 36^{\prime} 45^{\prime \prime} \mathrm{N}, 123^{\circ} 45^{\prime} 33^{\prime \prime} \mathrm{W}$

$49^{\circ} 39^{\prime} 4^{\prime \prime} \mathrm{N}-124^{\circ} 7^{\prime} 48^{\prime \prime} \mathrm{W}$

$46^{\circ} 15^{\prime} \mathrm{o}^{\prime \prime} \mathrm{N}-63^{\circ} 1^{\prime} 24^{\prime \prime}$

$48^{\circ} 39^{\prime} 22^{\prime \prime} \mathrm{N}-93^{\circ} 10^{\prime} 5^{\prime \prime} \mathrm{W}$ 


\section{Appendix 2 - Siren/Sirène/Sirenia place names in Canada}

(and ID numbers used in article)

\section{ID Location name}

CSo1 Île Sirène

CSo2 Lac de la Sirène

$\mathrm{CS}_{3}$ Lac de la Sirène

$\mathrm{Cso} 4$ Lac de la Sirène

CSo5 Lac Sirène

CSo6 Siren Creek

CSo7 Siren Lake
Province

Quebec

Quebec

Quebec

Quebec

Quebec

Ontario

Ontario

\section{Coordinates}

$48^{\circ} 25^{\prime} 50^{\prime \prime} \mathrm{N}-75^{\circ} 40^{\prime} 30^{\prime \prime} \mathrm{W}$

$49^{\circ} 35^{\prime} 45^{\prime \prime} \mathrm{N}-74^{\circ} 24^{\prime} 18^{\prime \prime} \mathrm{W}$

$47^{\circ} 50^{\prime} 17^{\prime \prime} \mathrm{N}-75^{\circ} 48^{\prime} 50^{\prime \prime} \mathrm{W}$

$48^{\circ} 51^{\prime} 30^{\prime \prime} \mathrm{N}-70^{\circ} 43^{\prime} 45^{\prime \prime} \mathrm{W}$

$47^{\circ} 42^{\prime} 29^{\prime \prime} \mathrm{N}, 71^{\circ} 33^{\prime} 27^{\prime \prime} \mathrm{W}$

$48^{\circ} 51^{\prime} 36^{\prime \prime} \mathrm{N}, 85^{\circ} 17^{\prime} 30^{\prime \prime} \mathrm{W}$

$48^{\circ} 53^{\prime} 32^{\prime \prime} \mathrm{N}, 85^{\circ} 13^{\prime} 19^{\prime \prime} \mathrm{W}$ 